\title{
Design of Interactive Digital Books: Learning Facilities Based on the 2017 Revision Spectrum of 2013 Curriculum
}

\author{
$1^{\text {st }}$ Patni Ninghardjanti \\ Universitas Sebelas Maret \\ Surakarta, Indonesia, Jl. Ir. \\ Sutami 36A Kentingan Jebres \\ Surakarta 57126 \\ buning@fkip.uns.ac.id
}

\author{
$2^{\text {nd }} C$. Dyah Indrawati \\ Universitas Sebelas Maret \\ Surakarta, Indonesia, Jl. Ir. \\ Sutami 36A Kentingan Jebres \\ Surakarta 57126 \\ ciciliadyahsulistyaningrum@yaho \\ o.com
}

\author{
$3^{\text {rd }}$ Andre Rahmanto \\ Universitas Sebelas Maret \\ Surakarta, Indonesia, Jl. Ir. \\ Sutami 36A Kentingan Jebres \\ Surakarta 57126 \\ andreyuda@gmail.com
}

\begin{abstract}
Education plays an important role in achieving educational goals, equally important to technology in improving the quality of learning. In addition, there is a need for new learning support facilities that are more interesting and effective in supporting the quality and quality of learning in schools, because it is increasingly sophisticated and the development of science and computerized technology. This study discussed the design of interactive digital archive books as a learning facilities based on the 2017 revision spectrum of 2013 curriculum. Interactive digital book is designed using Zmarbook aiming to facilitate the learning process, for both students and teachers. This interactive digital book makes the learning process more interesting, understandable, effective, and helpful to the learners to learn well and quickly, and can result in the efficiency of learning process that was once done manually using printed book.
\end{abstract} School

Keywords- Digital Book, Curriculum, Vocational

\section{INTRODUCTION}

Digitalization era brings about a very rapid change, starting with the turn of traditional into modern one. Human Resources (HR) is expected to be prepared for the changes occurring, so the quality of human must be improved in order to follow the changes taking place. In this case, the quality of human resources is encouraged and emphasized on the mastery and the establishment of hardskill and softskill capability in order to compete in the job market as a place to implement the competencies gained in education process to improve the quality of a nation.

The learning occurring in Vocational School (SMK) in Business and Management still uses teaching materials limited to the mastery of subject matter concept thereby impacting on the output of graduates who are not ready to plunge in business and industry world and the practice value obtained is not maximal. Therefore, learning must be in line with the purpose of SMK as a vocation school oriented to the work practices in order to produce the output of graduates really ready for working.

Teachers as professionals are expected to be competent in developing teaching materials in the form of interactive digital book itself, so that the development done will address the problems and difficulties of learners in the learning process taking place. Interactive digital book is expected to facilitate students in independent study (Liaw and Huang, 2014; Chen, 2013; Bradshaw, 2005), so that students can learn in accordance with their capabilities and can meet the competencies they must master. In this case, it refers to government programs related to policy and programming to fulfill the right of learners to obtain and use digital media facilities, so as to provide information and to support the learners in the learning process (Karim: 2011: 4, Andrea, Jenny, Joanna \& Amalia, 2016: 10); (Letchumanan, Malathi \& Tarmizi, 2010: 580).

In addition to the problems above, some other problems arise in the availability of teaching materials for the office administration of the 2013 curriculum: (1) Textbooks used is the one not equipped with clear practice sheets and practice instructions, (2) Student Activity Sheet (LKS) are not laboratory-oriented, still not achieving the standard process and content standards expected in the curriculum of 2013, (3) Teachers still have difficulty in finding reference sources relevant to learning materials, (4) The book used is still not interrelated between one discussion and another (5) Teachers have not made careful planning yet in preparing learning tools in supporting the creation of effective and quality learning. 


\section{METHOD}

The type of research conducted was Research and Development ( $R \& D$ ), because the end result or product expected from the development research should meet the existing criteria of new products or products that are different from the preexisting one and ready to be applied and developed in the field. The research was taken place in Vocational School throughout Surakarta Ex-Residency. The research procedure employed was in accordance with the stages proposed by Gall, Gall \& Borg (2003: 570571), encompassing: (1) Exploration Stage, (2) Development Stage Model Draft, (3) Stage Testing Model, and (4) Product Dissemination.

Type of data employed in this study was mix method (qualitative and quantitative data). Qualitative data was used in exploration and development stages, while quantitative data was used in test phase to find out the results of the developed model.

Data analysis technique used in this research was mix method. Considering this, the qualitative data was analyzed using interactive model of analysis (Miles \& Huberman, 1992: 20), while the quantitative data using descriptive statistic technique and variance test.

\section{RESULTS AND DISCUSSION}

The learning implemented in the classrooms provides some supporting facilities such as: laptop, smartphone, LCD, and sound. The development of interactive digital book starts with preparing text, images, video required in the learning materials, the process of developing a 2013 curriculum-based archiving interactive digital book include the development of material compilation in accordance with the syllabus of archiving subjects using main software Zmartbook. Zmartbook can load images, text, and video so that learners can be interested in following the learning and can facilitate the earners' understanding on the existing subject matter. At this stage it is necessary to edit and revise the material of the archiving interactive digital book based on the 2017 revision spectrum of 2013 curriculum used in the archiving learning process.

\section{Interactive Digital Book Cover Display}

Interactive Digital Book Cover is a part of book becoming one layer of digital books.

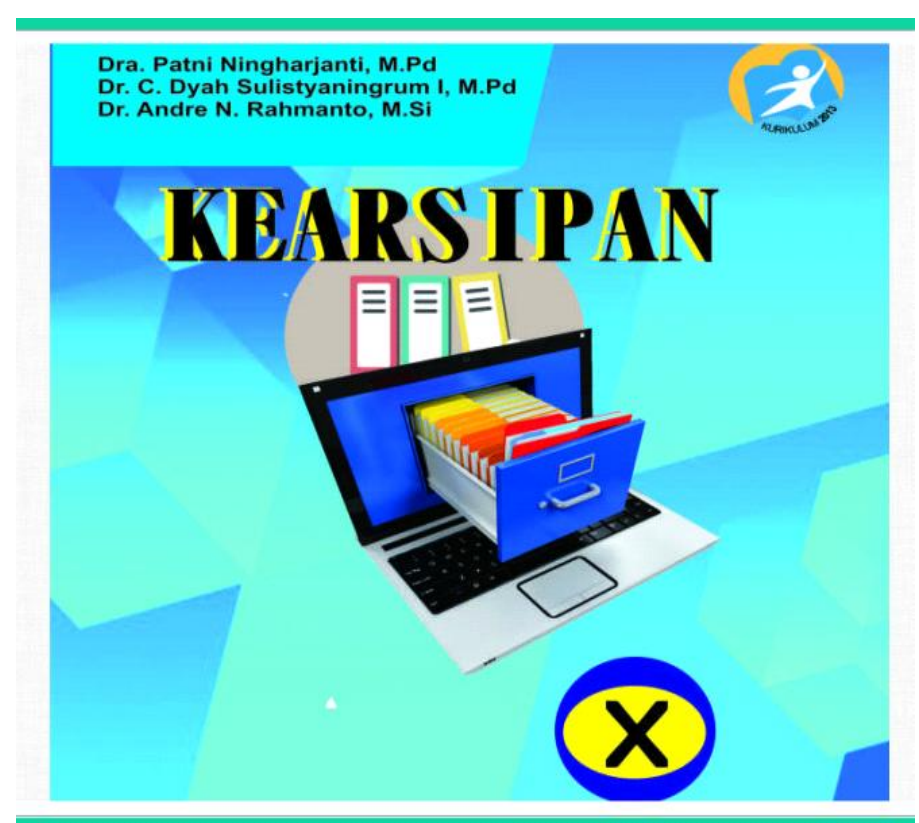

Figure 1. Interactive Digital Book Cover

\section{Display Table of Contents}

The table of contents is a page guiding the main content in the archiving Interactive digital book based on the 2013 curriculum of 2017 revision spectrum. The table of contents can facilitate the readers to know the part or layout of material contained in the archiving Interactive digital book based on the 2013 curriculum of 2017 revision spectrum.

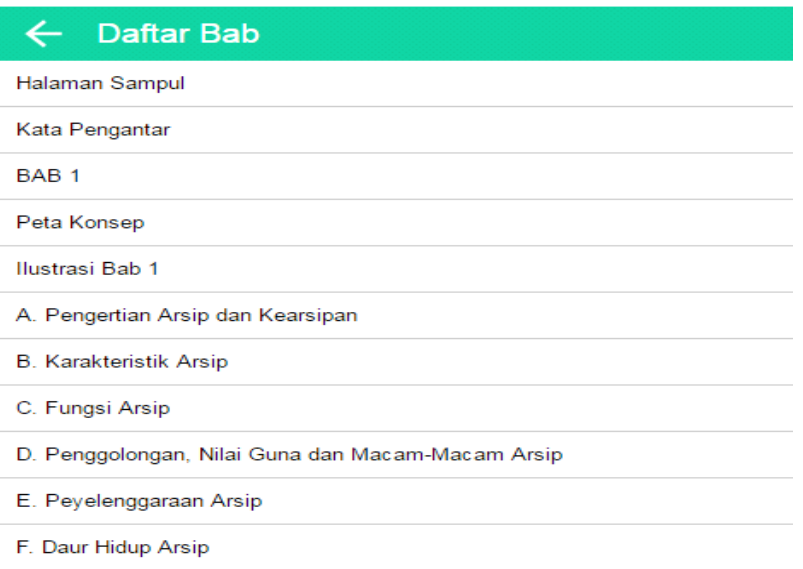

Figure 2. Table of Contents View 


\section{Concept Map}

\section{PETA KONSEP}

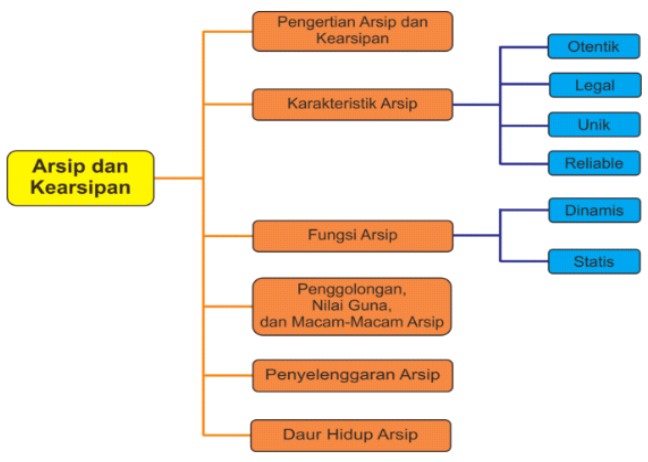

Figure 3. Concept Map

4. Material Display
6) Assignment Display

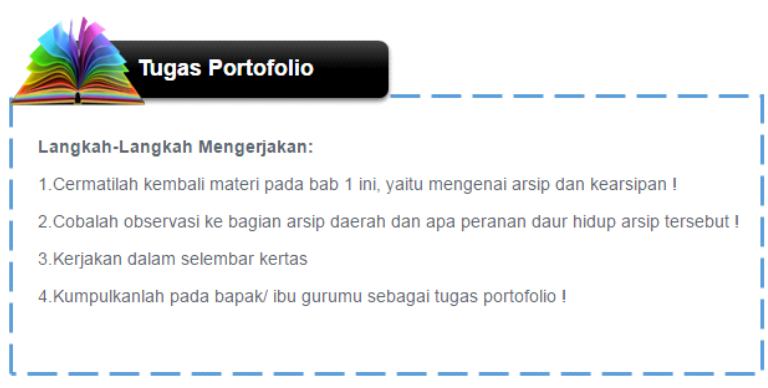

Tugas Proyek

Langkah-Langkah Mengerjakan:

Buatlah kelompok 4-5 orang dengan teman sekelasmu

Buatlah sebuah presentasi dengan media pembelajaran mengenai materi pada bab 1 ini ! Kemudian presentasikan di depan kelas ।

\section{B. KARAKTERISTIK ARSIP}

Arsip mempunyai karakter yang disebut dengan karakteristik arsip. Berdasarkan karakteristik yang ada dapat membedakan kualitas dari arsip, karakteristik dari arsip sebagai berikut

1. Otentik

Arsip sebagai informasi yang melekat dengan wujud aslinya (kecuali arsip elektronik), seperti isi, struktur dan konteksnya sehingga Informasi mengenai waktu dan tempat arsip diciptakan atau diterima memiliki arti atau makna yang berfokus pada tujuan dan kegiatan suatu organisasi.

2. Legal

Arsip yang digunakan sebagai dokumentasi dapat mendukung tugas dan kegiatan, memiliki status sehingga dapat dijadikan sebagai bahan bukti resmi bagi keputusan dan pelaksanaan kegiatan.

\section{Figure 4. Material Display}

5. Video View
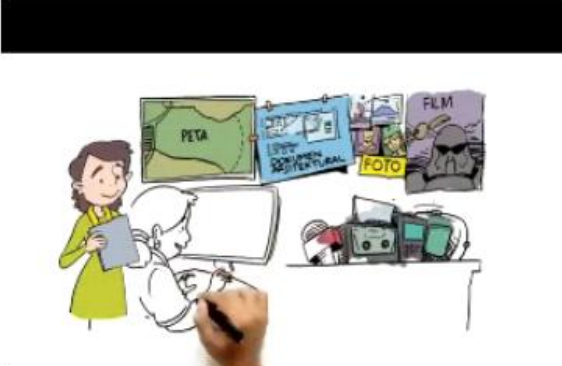

Figure 5. Video View
Figure 6. Assignment Display

7) Evaluation Display

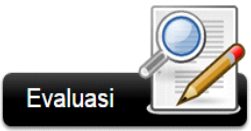

$$
\begin{aligned}
& \text { I. Pilihlah jawaban yang tepat } \\
& \text { 1. Contoh arsip dinamis, kecuali.... } \\
& \text { a. Tata tertib sekolah } \\
& \text { b. Visi-Misi sekolah } \\
& \text { c. Jadwal ruang } \\
& \text { d. Kemajuan kelas } \\
& \text { e. Daftar siswa yang sudah lulus }
\end{aligned}
$$

2. Arsip yang masih dipergunakan terus menerus bagi kelangsungan pekerjaan dilingkungan unit pengolahan suatu organisasi, meruakan pengertian dari ...

$$
\begin{aligned}
& \text { a. Arsip aktif } \\
& \text { b. Arsip inaktif/pasif } \\
& \text { c. Arsip statis } \\
& \text { d. Arsip sekunder } \\
& \text { e. Arsip Primer }
\end{aligned}
$$

\section{Figure 7. Evaluation Display}

Having revised the digital book developed, the next step is to conduct trials with the learners in the learning process. The following is a validation conducted by material experts, practitioners and media experts:

\section{Table 1 Result of Validation by Material Experts}

Table 1 shows that the result of material expert 
validation obtains mean score of 5 for aspects of the contents of the material. Meanwhile the learning aspect obtains mean score of 4.8. Considering the result of validation by material experts, it has mean score of 4.9 belonging to very good category and it can be said that the learning material content of archiving interactive digital book based on the curriculum 2013 belongs to very good category.

Table 2 Result of Practitioner Validation

\begin{tabular}{|c|c|c|c|c|}
\hline Number & Aspect & $\begin{array}{c}\text { Average } \\
\text { Score }\end{array}$ & Category & $\begin{array}{c}\text { Average } \\
\text { Aspect }\end{array}$ \\
\hline 1 & Contents & 4,8 & $\begin{array}{c}\text { Very } \\
\text { good }\end{array}$ & 4,8 \\
\hline 2 & Learning & 4,9 & $\begin{array}{c}\text { Very } \\
\text { good }\end{array}$ & 4,9 \\
\hline
\end{tabular}

Table 2 shows that the result of practitioner validation obtained mean score of 4.8 for material content aspect. Meanwhile the learning aspect obtains mean score of 4.9. Considering the result of practitioners validation, it has mean score of 4.85 meaning that it belongs to very good category and it can also be said that the learning material content of archiving interactive digital book based on the 2017 revision spectrum of 2013 curriculum belongs to very good category.

Table 3 Result of Media Expert Validation

\begin{tabular}{|c|c|c|c|c|} 
Number & Aspect & $\begin{array}{c}\text { Average } \\
\text { Score } \\
4,8\end{array}$ & $\begin{array}{c}\text { Category } \\
\text { Very } \\
\text { good }\end{array}$ & $\begin{array}{c}\text { Average } \\
\text { Aspect } \\
4,8\end{array}$ \\
\hline 2 & Balance & 5 & $\begin{array}{c}\text { Very } \\
\text { good }\end{array}$ & 5 \\
\hline 3 & Color & 4,7 & $\begin{array}{c}\text { Very } \\
\text { good }\end{array}$ & 4,7 \\
\hline 4 & Language & 5 & $\begin{array}{l}\text { Very } \\
\text { good }\end{array}$ & 5 \\
\hline 5 & Interactivity & 4,8 & $\begin{array}{l}\text { Very } \\
\text { good }\end{array}$ & 4,8 \\
\hline
\end{tabular}

Table 3 shows that the result of questionnaire in media expert validation obtains mean scores of 4.8 for integration,. 5 for balance, 4.7 for color, 5 for language, and 4.8 for media interactivity aspects. Considering the results of validation by media experts, it has mean score of 4.86 belonging to very good category and it can be said that the archiving interactive digital book based on the 2017 revision spectrum of 2013 curriculum belongs to very good category so that the media is very feasible to apply to the learning process.

The structure of writing used in digital books is very good, so the material discussed can facilitate the learners to understand better the material discussed.
The developed digital books can make the classroom an Active, Innovative, Creative, Effective, and Joyful Learning (PAIKEM). Digital Book is a means of following the development and advancement of technology supporting the learning optimally. It is in line with Roesnita \& Zainab A.N's study (2005: 10) in a journal entitled The Pattern of E-Book Use Amongst Undergraduates in Malaysia: A Case of to Know is To Use finding that digital book is usable and is used particularly in task writing and project work. It can indirectly improve the effectiveness of learning. Effectiveness is the ability to achieve objective welfare and effectiveness as the expedience obtained after learning activity (Dirgatama, 2017: 5)

\section{CONCLUSION}

The development of an interactive digital book of archiving based on 2017 revision spectrum of 2013 curriculum is conducted using Gall, Gall \& Borg's development model (2003: 570-571), encompassing: (1) Exploration Stage, (2) Stage of Draft Model Development, and (3) Stage Testing Model, Product Dissemination. The feasibility of the archiving digital book based on the 2013curriculum is reviewed based on the assessment conducted by material experts, practitioners, and media experts. The assessment by material experts obtains mean score of 4.9 (very good category), that of practitioners gains mean score of 4.85 (very good category), and that of media experts obtains mean score of 4.86 (very good category). Validation results indicate that this digital book is very good as a means of digital learning in support of archival learning

Interactive digital books contribute to improving the quality and quantity of classroom learning. Interactive Digital books can help educators deliver teaching materials, thereby giving added value to the learning activities.

\section{ACKNOWLEDGEMENTS}

Thank to Research institutions and community service of Sebelas Maret University and Subject Teacher Discussion (MGMP) of Office Administration teachers throughout Surakarta ExResidency.

\section{REFERENCES}

[1] Andrea, Jenny, Joanna \& Amelia. (2016). "Using E-Books to Create Shared Learning Experiences Between Students of Differing Abilities." Journal of Occupational Therapy, Schools, \& Early Intervention 9(1): 12-18.

[2] Letchumanan, Malathi \& Tarmizi, R. A. (2010). "Utilization of E-Book among University Mathematics Students." Journal Elsevier: Social and Behavioral Sciences 8(1): 580-587.

[3] Karim, Abdul. (2011). "The Effectiveness of Individual Self-Learning Computer Simulated and Electronic Book in the Development of Innovative Thinking Among Science Students in Second Year, Faculty of Education, Sultanate of Oman (Experimental Study)." Journal of the 
Faculty of Education, University of Assiut 27(2): 1-9.

[4] Miles, M.B. and Huberman, A.M. (1992). Analisis Data Kualitatif: Buku Sumber Tentang Metode Metode Baru. UI Press. Jakarta.

[5] Dirgatama, Chairul. (2017). "The Effectiveness Of Archived E-Book Based Curriculum 2013 As An Effort To Improving Learning Outcomes In Vocational School." Journal of Education and Learning 11(3): 405-410.

[6] Roesnita \& Zainab A.N. (2005). "The Pattern of E-Book Use amongst Undergraduates in Malaysia: A Case of to Know is to Use."
Malaysian Journal of Library \& Information Science 10(2): 1-23.

[7] Liaw \& Huang (2014). "Investigating Learner Attitudes toward E-Books as Learning Tools: Based on the Activity Theory Approach." Journal Interactive Learning Environments. ISSN: 1049-4820.

[8] Chen, H. Y. (2013). "Exploring the Reasons for Using Electric Books and Technologic Pedagogical and Content Knowledge of Taiwanese Elementary Mathematics and Science Teachers." Journal TOJET: Educational Technology 12(2): 131-141. 